\title{
Measuring the Degree of Internationalization for Taiwanese Banking Industry: Scoring Measurement by Principal Component Analysis
}

\author{
Hsiang-Hsi Liu ${ }^{1}$, Wang-Chiang $\mathrm{Ko}^{2}$ \\ ${ }^{1}$ Distinguished Professor, Graduate Institute of International Business, National Taipei University, Taipei, \\ Taiwan \\ ${ }^{2}$ Master, Graduate Institute of International Business, National Taipei University, Taipei, Taiwan \\ Correspondence: Hsiang-Hsi Liu, Distinguished Professor, Graduate Institute of International Business, National \\ Taipei University, Taipei, Taiwan.
}

Received: April 24, 2017

doi:10.5539/ibr.v10n6p212

\author{
Accepted: May 13, 2017 \\ Online Published: May 22, 2017 \\ URL: https://doi.org/10.5539/ibr.v10n6p212
}

\begin{abstract}
This paper mainly focuses on researching and measuring the effects concerning the degree of internationalization (DOI) within the Taiwanese banking industry, with particular application of the scoring measurement by principal component analysis (PCA). The empirical results indicate that there exits an increasing trend for the DOI of Taiwanese banking industry as measured by FATA (each bank's overseas assets over its own total assets), FETE (each bank's overseas equities over its own total equities), FSTS (each bank's overseas sales over its own total sales) and FBTB (each bank's overseas facilities and operating units over its own total operating units). Under the Box-cox transformation, the DOI scoring index as percentage level (\%) from 0 to 100 shows that the relevance of the variables are mostly above 50, indicating that the DOI of the observed Tai wanese banks are quite strong. Thus, the results support the existence and importance of the DOI for current Taiwanese financial institutions, while presenting complimentary and more realistic information regarding the degree of internationalization for Taiwanese banks. At the same time, providing substantial groundwork and adding value to future international management research and investigations that could help representatives of government and management decision makers to achieve better investment decision-making for business strategies and prompt international expansion.
\end{abstract}

Keywords: banking industry, country-institution Factors, Degree of Internationalization (DOI), principal component analysis

\section{Introduction}

As an island nation, Taiwan is very much dependent on internationalization situations, and thus, has also been subsequently affected by the recent overall world turmoil and past financial global situations. However, despite recent downturns, the overall global economy still seems to be set for a moderate recovery, and Tai wan is strong to follow on global economic trends (Chen, 2012). In this regard, hopefully Taiwan's financial institutions would further lead on and not be substantially impacted, continuing to expand their business horizons globally and work towards de veloping their international presence. Under these circumstances, this research aims to better understand the situations regarding the degree of internationalization of Taiwanese banks. So far, little interest has been expressed in determining the degree of internationalization for the Taiwanese banking industry, and to do so, it thus requires the necessary groundwork research. This article focuses on measuring the degree of internationalization (DOI) within the Taiwanese banking industry, where the phenomenon can be most clearly identified, whilst also considering the particular application of the scoring measurement by principal component analysis (PCA).

When Tai wanese banks seek to enhance internationalization, not only do they need to take into account factors benefiting the firm, but they might also need to consider factors that interact with the foreign county. In the ory, internationalization is the process of increasing involvement of enterprises in international markets. There are several internationalization theories which try to explain the drivers behind international activities. International trade by definition is the exchange of capital, goods, and services across international borders or territories, which could involve the activities of governments and indi viduals. As of which, in Tai wan, internationalization not only involves the manufacturing and trading of products and goods, but it also involves the transaction of 
services such as banking, insurance and other financial services like foreign direct (portfolio) investments. According to De Bonis, Ferri, and Rotondi (2015), when a non-financial enterprise (especially manufacturing sector) enjoys a strong relationship with its main bank, internationalization is more likely. Moreover, the positive impact of relationship banking is greatest when the firm's main bank is itself internationalized. By better understanding and measuring the degree of internationalization of Taiwanese Banks, it would be possible to more accurately understand the necessary implications regarding the internationalization of Taiwanese financial institutions and how it could potentially influence the country's global expansion across industries and also as a whole, as financial service companies often play a crucial role and have a close relationship with other firms that invest overseas (Seth, Nolle \& Mohanty, 1998).

The internationalization of Taiwanese banks could be said with certainty tied closely to the internationalization of other firms, as financial institutions provide the necessary pathway for international business and overseas investment. In this regard, while the Tai wanese banking industry seeks effort to extend their scope abroad, the exploration on the degree of internationalization and its measurements thus become substantial issues for Tai wanese and global operators to address within domestic and likewise also on the worldwide spectrum. Hopefully, banking management and policy makers could use the results from this research to analyze the country's global expansion issues while considering more realistic information regarding the degree of internationalization for Taiwanese banks, and at the same time provide substantial groundwork and adding value to future international management research and investigations. Meanwhile, it could also help achieve better investment decision-making for business strategies purposes and government policies.

The reminders of this study are organized as follows. Section 2 describes the general trends of internationalization for Taiwanese banking industry. Section 3 discusses the related theories and a review of the relevant literature. Section 4 presents the methodology of principal component analysis. Section 5 depicts the empirical measurement of DOI for Taiwanese banking industry and implications. Section 6 provides the concluding remarks.

\section{General Trends of Internationalization for Tai wanese Banking Industry}

In this section, we will analyze the general trends of internationalization for the Tai wanese banking industry, where Section 2.1 will briefly describe the actual internationalization regions and locations of Tai wanese banks up to 2015 and Section 2.2 will briefly discuss a general view related to actual internationalization for Tai wanese banks.

\subsection{Internationalization Regions and Locations of Taiwanese Banks up to 2015}

In the broad sense, internationalization refers to the expansion of an enterprise's products or activities into overseas markets. The term can thus be applied to exports, licensing, agency operations, export processing, etc., where it does not necessarily involve foreign direct investment (FDI). In a narrower sense, as according to the definition used by the United Nations Conference on Trade and Development (UNCTAD), for an enterprise to be classed as a transnational corporation it must have established an entity overseas, and that entity must operate within the same decision-making system as the parent company. As such, under this situation, for the purposes of this research we thus focus on the Taiwanese banking institutions that have already established subsidiaries overseas.

The overall financial institutions in Taiwan are mostly involved in indirect financing and money market activities; they include commercial banks, industrial banks, the Postal Remittances, financial holding companies, local branches of foreign banks, credit cooperatives, and bills finance companies. In this regard, the total number of operating branches in Tai wan has surpassed 5,098 as of 2015. Of all, commercial banks are relatively larger in terms of their net worth, assets, and network of branches. In fact, 16 Taiwanese banks rank among the top 500 banks in the world in terms of tier one capital, according to the July 2014 issue of the Banker. As provided by data from the Taiwanese Financial Supervisory Commission, by the end of September 2015 Taiwan was home to 39 Taiwanese commercial banks, out of which we select 18 that already operate overseas as having established numerous branches, representative offices and other affiliates in different regions and locations.

As we can see from the Table 1, Taiwanese banks have overall expanded overseas into 6 regions, namely: Asia-Pacific (Mainland China, Japan, Indonesia, India, Cambodia, Hong Kong, Thailand, Malaysia, Philippines, Vietnam, Singapore, Lao PDR, Myanmar, Australia and Macau) Asia-Middle East (Bahrain and United Arab Emirates), Europe (Belgium, France, United Kingdom and Netherlands), North America (Canada, US), Central-South America (Panama) and Africa (South Africa). The 18 Taiwanese domestic banks together have in total 433 branches, representative offices and other. 
Table 1. Branches, Representative Offices and Other Affiliates in Different Regions and Locations (2015)

\begin{tabular}{|c|c|c|c|c|c|}
\hline Countries & Institutions & Total & Branches & $\begin{array}{c}\text { Representative } \\
\text { Offices }\end{array}$ & $\begin{array}{c}\text { Other } \\
\text { Affiliates }\end{array}$ \\
\hline & Grand Total & 433 & 127 & 31 & 275 \\
\hline & Subtotal & 343 & 93 & 28 & 222 \\
\hline \multirow{15}{*}{ Asia-Pacific } & Mainland China & 56 & 24 & 3 & 29 \\
\hline & Japan & 42 & 6 & - & 36 \\
\hline & Indonesia & 13 & - & 1 & 12 \\
\hline & India & 4 & 2 & 2 & - \\
\hline & Cambodia & 34 & 3 & 1 & 30 \\
\hline & Hong Kong & 68 & 20 & 3 & 45 \\
\hline & Thailand & 9 & - & 4 & 5 \\
\hline & Malaysia & 4 & 2 & - & 2 \\
\hline & Philippines & 31 & 2 & 1 & 28 \\
\hline & Vietnam & 55 & 11 & 9 & 35 \\
\hline & Singapore & 10 & 10 & - & - \\
\hline & Lao PDR & 2 & 2 & - & - \\
\hline & Myanmar & 4 & - & 4 & - \\
\hline & Australia & 8 & 8 & - & - \\
\hline & Macau & 3 & 3 & - & - \\
\hline \multirow{3}{*}{ West-Asia } & Subtotal & 2 & - & 2 & - \\
\hline & Bahrain & 1 & - & 1 & - \\
\hline & United Arab Emirates & 1 & - & 1 & - \\
\hline \multirow{5}{*}{ Europe } & Subtotal & 9 & 7 & - & 2 \\
\hline & Belgium & 1 & - & - & 1 \\
\hline & French & 1 & 1 & - & - \\
\hline & United Kingdom & 6 & 5 & - & 1 \\
\hline & Netherlands & 1 & 1 & - & - \\
\hline \multirow{3}{*}{ North America } & Subtotal & 76 & 24 & 1 & 51 \\
\hline & Canada & 11 & 2 & - & 9 \\
\hline & U.S.A. & 65 & 22 & 1 & 42 \\
\hline \multirow[b]{2}{*}{ Central-South America } & Subtotal & 2 & 2 & - & - \\
\hline & Panama & 2 & 2 & - & - \\
\hline & Subtotal & 1 & 1 & - & - \\
\hline Africa & South Africa & 1 & 1 & - & - \\
\hline
\end{tabular}

Source: Financial Supervisory Commission

affiliates overseas, how they are spread across each region is shown in Figure 1, where, $79 \%$ belongs to the Asia-Pacific region, $18 \%$ is located in the North America Region and 2\% is situated in the Europe area. Overseas branches and representative offices established across nations indicate that Taiwanese banks have indeed already experienced a certain degree of internationalization.

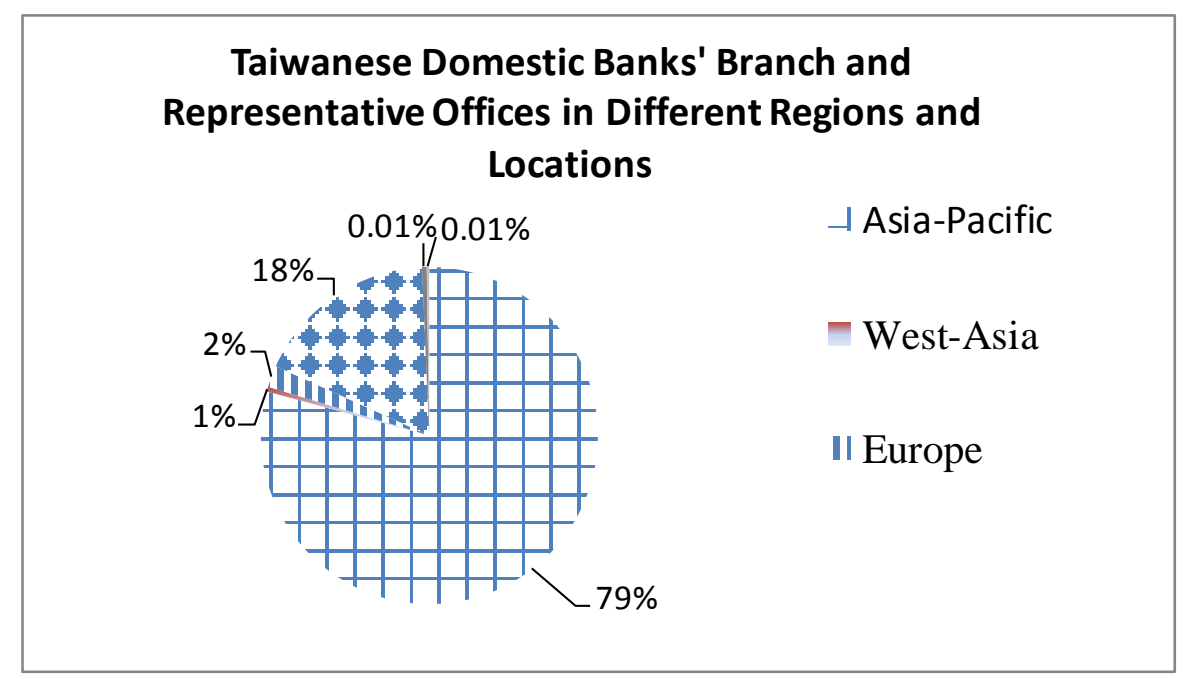

Figure 1. Taiwanese Domestic Banks' Branches, Representative Offices and Other Affiliates Source: Financial Supervisory Commission 


\subsection{General View of Actual Internationalization for Taiwanese Banks in Different Regions and Locations}

Here we separately examine the degree of internationalization for Taiwanese banks by looking at the four different index ratios that could be applied to measure the DOI of each bank.

FATA: each bank's overseas assets over its own total assets

FETE: each bank's overseas equities over its own total equities

FSTS: each bank's overseas sales over its own total sales

FBTB: each bank's overseas facilities and operating units over its own total operating units

We selected these categories based on internationalization components as indicated in previous literatures (Sullivan, 1994) and also taking into consideration of the real business activity of Taiwanese banks operating overseas. Based on data collected from the Central Bank of the Republic of China (Taiwan), Financial Supervisory Commission (Banking Bureau) and Taiwan Economic Journal (TEJ), we could then construct the estimated values to detect each of the four different ratios for each bank. Table 2 shows the average of each of the indexes for each selected Tai wanese bank during the study period 2000-2015. These measurements of DOI in general can thus show the reality of internationalization of the banking industry in Taiwan.

Regarding FATA as each bank's overseas assets over its own total assets, the average value of DOI of Taiwanese banks estimated by FATA is 0.001 , ranking in the first five are:

1. Mega Bank

2. CTBC Bank

3. Bank SinoPac

4. Shanghai CSB

5. First Bank

Regarding FETE as each bank's overseas equities over its own total equities, the average value of DOI of Taiwanese banks estimated by FETE is 0.0003 , ranking in the first five are:

1. First Bank

2. Mega Bank

3. Hua Nan CB

4. E.Sun Bank

5. Cathay United Bank

Regarding FSTS as each bank's overseas sales over its own total sales, the average value of DOI of Taiwanese banks estimated by FSTS is 0.001 , ranking in the first five are:

1. Land Bank

2. Ta Chong bank

3. Mega Bank

4. Bank SinoPac

5. TaipeiFubon Bank

Regarding FBTB as each bank's overseas facilities and operating units over its own total operating units, the average value of DOI of Taiwanese banks estimated by FBTB is 0.022 , ranking in the first five are:

1. CTBC Bank

2. Mega Bank

3. Bank SinoPac

4. Cathay United Bank

5. First Bank

As such, based on Table 2 regarding the four different index measurement ratios for the degree of internationalization for Taiwanese banks in general each index can actually show that Taiwanese banks in fact already have a substantial amount of internationalization. As criticized by Sullivan (1994), by using only single index measurement, it may lead to undervaluation of the DOI. Each measurement from the different single index 
yield different partial results for the DOI measurement of Taiwanese banks, as such it cannot completely justify the actual DOI for Taiwanese banks. Therefore, this study will consider an integrated/Composite index as proposed by Sullivan (1994) by using principal component analysis to combine and integrate the different aspects regarding the degree of internationalization of Taiwanese banks as shown in the conceptual model in Figure 2.

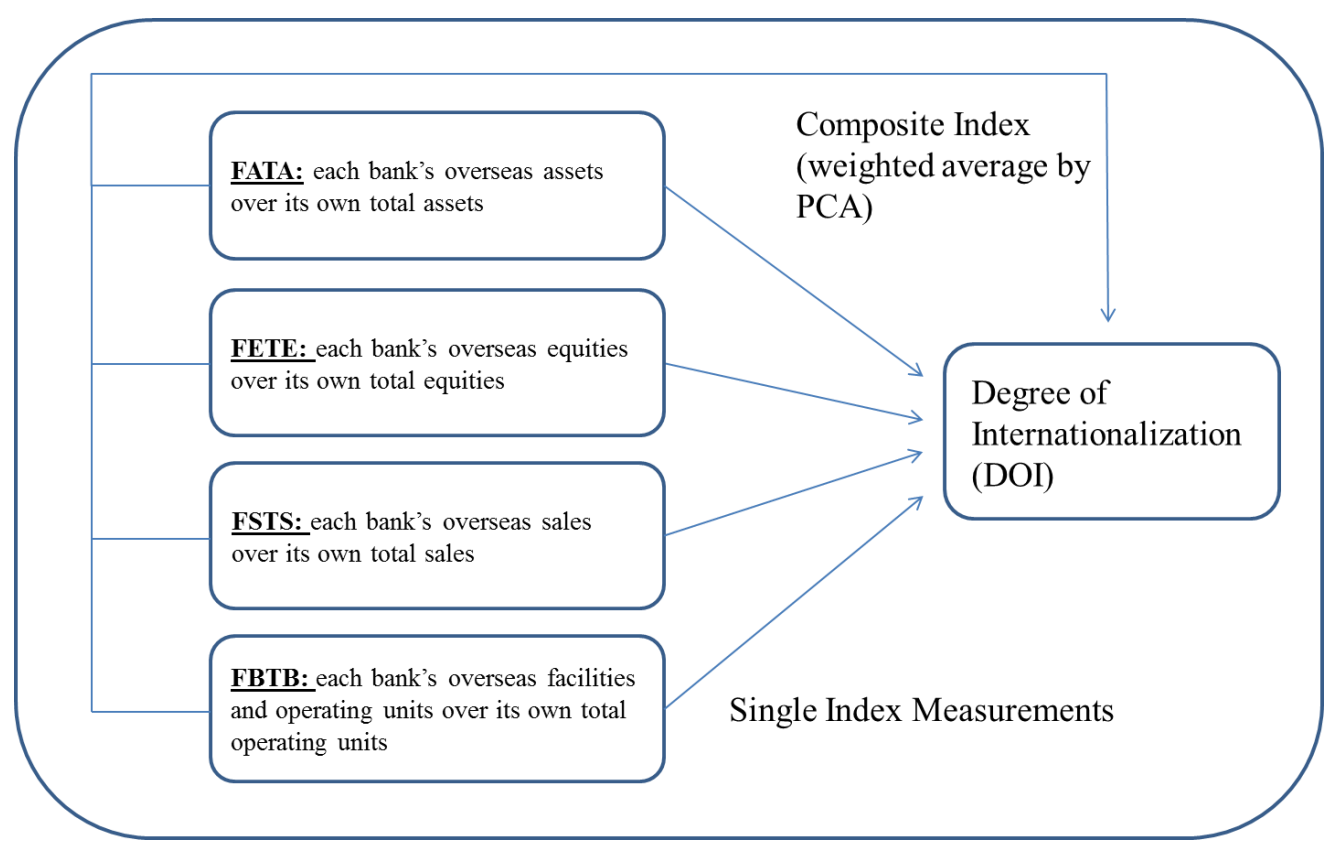

Figure 2. Conceptual Framework

Source: This Study

\section{Related Theories and Literature Review}

\subsection{Concepts, Measurements and Related Theories of Internationalization}

In this study we will investigate the DOI of Taiwanese banking industry, as such, this section will discuss the definition of internationalization, process of internationalization, motivation and drivers of internationalization, contents of internationalization, benefits of internationalization and finally, the relevant measurements regarding internationalization.

\subsubsection{Definition of Internationalization}

The general definition of internationalization is the process of designing and executing of a product or a service so that it will meet the needs of users in many countries or can be easily adapted to the local culture.

Table 2. Four Different Index Ratios of DOI

\begin{tabular}{|c|c|c|c|c|c|c|c|c|c|c|c|c|c|c|c|c|c|c|c|}
\hline & & Bank & & & & & Hua & Cathay & Chang & & & & & & Tairwan & Shin & Far & $\mathrm{Ta}$ & Average \\
\hline & Mega & of & CTBC & First & $T C B$ & TaipeiFubon & Nan & United & Hwa & Land & ESun & Shanghai & Bank & Taishin & Business & Kong & Eastem & Chong & \\
\hline DOI & Bank & Taivan & Bank & Bank & Bank & Bank & $C B$ & Bank & Bank & Bank & Bank & $\operatorname{CSB}$ & $\mathrm{SinOPac}$ & $\operatorname{Int} B$ & Bank & Bank & Bank & bank & \\
\hline FATA & $4 \mathrm{E}-04$ & 8E-05 & $2 \mathrm{E}-04$ & 2E-04 & SE-05 & $1 \mathrm{E}-04$ & 1E-04 & $1 \mathrm{E}-04$ & 1E-04 & $4 \mathrm{E}-05$ & IE-O4 & $2 \mathrm{E}-04$ & EE-04 & $1 \mathrm{E}-04$ & $8 \mathrm{E}-05$ & SE-05 & 9E-05 & 1E-04 & $1 \mathrm{E}-04$ \\
\hline FETE & 9E-05 & $4 \mathrm{E}-05$ & SE-05 & 2E-04 & 4E-05 & $5 \mathrm{E}-05$ & TE-05 & $6 \mathrm{E}-05$ & $5 E-05$ & $4 \mathrm{E}-05$ & $6 \mathrm{E}-05$ & $2 \mathrm{E}-05$ & $2 \mathrm{E}-05$ & $2 \mathrm{E}-05$ & $5 \mathrm{E}-05$ & $2 \mathrm{E}-05$ & $\mathbb{E}-05$ & $3 \mathrm{E}-05$ & SE-05 \\
\hline FSTS & 6E-04 & 3E-04 & 4E-04 & 3E-04 & $2 \mathrm{E}-04$ & SE-04 & $3 \mathrm{E}-04$ & 1E-04 & $3 \mathrm{E}-04$ & 0.002 & $4 \mathrm{E}-04$ & $3 \mathrm{E}-04$ & $6 \mathrm{E}-04$ & $2 \mathrm{E}-04$ & $-1 \mathrm{E}-04$ & 2E-04 & $1 \mathrm{E}-04$ & 0.001 & EE-O4 \\
\hline FBTB & 0.24 & 0.052 & 0.356 & 0.106 & 0.026 & 0.054 & 0.045 & 0.179 & 0.042 & 0.032 & 0.046 & 0.052 & 0.209 & 0.024 & 0.0289 & 0.012 & 0.025 & 0.01 & 0.086 \\
\hline Average & 0.06 & 0.013 & 0.089 & 0.027 & 0.006 & 0.014 & 0.011 & 0.045 & 0.011 & 0.009 & 0.012 & 0.013 & 0.052 & 0.006 & 0.0072 & 0.003 & 0.006 & 0.003 & 0.022 \\
\hline
\end{tabular}

Source: This Study

\subsubsection{Process of Internationalization}

Johanson and Vahlne (1977) indicated that internationalization of firms is a process in which the firms progressively increase their international involvement. Particularly on the gradual acquisition, integration, and use of knowledge about foreign markets and operations, and on the successively increasing commitment to 
foreign markets. Johanson and Vahlne (1977) further examine the steps that are taken to constitute the internationalization process of a firm. First are process-decisions that start the initial export to a country, then it is to establish export channels, in order to start sales branches and subsidiaries, and finally to achieve overseas direct investments as the final step in the process of firm internationalization. More specifically the proce ss of internationalization can be described as: exporting, international licensing and franchising, strategic alliances, joint ventures, mergers and acquisitions; each of them with increased level of involvement and control, finally achieving a wholly owned entity.

On another note, Nilsson, Olofsson and Sennevik (2005) suggested that the process of internationalization has its theoretical foundation in the behavioral theory of the firm and in the growth of the firm itself. The process between these two theories creates an interaction between the knowledge development about foreign markets, operations and the increasing commitment of resources to the market abroad. They also believe that internationalization has its base in state aspects and change aspects, where state aspects consist of market commitment and market knowledge, and the change aspect refers to current business activities and commitment decisions.

\subsubsection{Motivation and Drivers of Internationalization}

There are many motivations and drives that firms choose to internationalize and expand abroad. Dunning (1980) mainly distinguished the four general types of overseas investment motivations: 1) market-seeking, which purpose is to serve local and regional markets, so the size of market or the market's growth is important determinants in this type, 2) efficiency-seeking, it will occur when out ward investors seek lower-cost locations for operations, in particular in the search for lower cost labor, 3) resource-seeking occurs when firms invest abroad to acquire resources that are not available in home country, 4) strategic assets-seeking which is not just exploiting an existing ownership-specific advantage of an investing firm, but more protecting or augmenting that advantage by the acquiring new assets, or by a partnering arrangement with a foreign firm, 5) oligopoly interaction, when in a oligopolistic market competitors often do not let the other party move first into a new market, they will try to enter first and achieve first mover advantage and 6) follow the customer, firms may expand internationally in order to follow customers that have already established overseas. Following the above sense of foreign investment motivations, this information provides us the necessary means to determine the major reasons and drivers which affect the degree of internationalization of a firm.

Following on the above discussions, there are also two main forces, push and pull, that might lead firms to internationalize. Push forces are those such as rising labor cost in host country, or powerful competitors in home country that inevitably pushes the firm out (Manjón-Antolín \& Arauzo-Carod, 2011; Wright, 2002) when the overall situation is no longer inside the spatial margins to profitability. Pull forces can include the factors which attract firms and pull them out of their present location to internationalize into a new place, such as market potential, lower labor cost, political stability and trade agreements between home and host country (Brouwer, Mariotti \& Van Ommeren, 2004).

For the banking industry, the internationalization of financial instruments can diverse the risk and also expend their business to overseas markets offering diversified services. Lin and Huang (2013) also mentioned that when facing a shrinking market, enterprise will have to resort to internationalization. Internationalization is the procedure of organizing and utilizing global economic resources, such as capital, raw material, labor, information, market and management. By strengthening the global presence, firms can make up for the lack of domestic resources and gain a better performance.

\subsubsection{Contents of Internationalization}

Annavarjula and Beldona (2000) reported that Internationalization of a firm refers to the extent to which firms operate internationally by investing in assets and/or controlling activities outside their home country (Sanna-Randaccio, 1996). There are several ways in which an organization can be defined as an international firm. These can be broadly classified as ownership, operations, and orientation.

\subsubsection{Ownership}

Ownership refers to the extent to which a company owns value-generating assets abroad, as well as the extent to which it is owned by indi viduals and institutions abroad. A MNC might own assets abroad, such as land or real estate, or hold stock in another company that may result in a controlling interest in that foreign company. For example, Shell Oil Company owns oil refineries in Sudan, gas stations in Brazil, and restaurants in France. These businesses are run by Shell's personnel and generate economic rents to Shell. On the other hand, foreign individual or institutional investors could own an MNC; its stocks may be traded in multiple stock exchanges 
both at home and abroad. It may also be that individuals or institutions from more than one country may own a domestic company.

\subsubsection{Operations}

A firm may source its physical and intellectual inputs overseas, it could also base its production activities overseas, or it could locate its sales/service activities (Dunning, 1980). Porter (1990) calls these "val ue activities". Accordingly, conceptualizations of MNCs can be made in terms of the "content" of these value-adding activities. For example, the proportion of overseas sales to total sales, overseas subsidiaries to total subsidiaries, overseas employees to total employees, etc.--the overall assumption being that the larger the total number of foreign countries involved or the higher the overall level of overseas operations, the more the firm is "multinationalized."

Thus, while consumer goods conglomerate Procter and Gamble is a multinational that has significant foreign production capabilities, petroleum giant Royal Dutch-Shell is a multinational with significant foreign sales generated by its numerous foreign subsidiaries. Pharmaceutical firms like Merck and Hoechst are multinationals that conduct significant overseas research and development (R\&D) activities in addition to overseas sales. Automobile giants Honda, Toyota, and Mitsubishi are multinationals known for their significant foreign assets in addition to their manufacturing and sales activities abroad.

\subsubsection{Orientation}

Orientation indicates the attitudinal posturing or "intent" of the multinational company and its management in terms of its vision, strategy, and structure. Perlmutter (1969) classified such posturing as ethnocentric, polycentric, regiocentric, or geocentric depending on the relative importance that a MNC attaches to its strategy. This, in turn, sets the tone for the decision making of the firm. For example, an ethnocentric orientation suggests that the firm is more likely to extend the strategies and decisions that have originated in the home country into the host country, based on the assumption that these are globally applicable. A geocentric approach is quite the opposite in that it is more situation and contingency driven.

\subsubsection{Measurements of Internationalization}

Hitt, Tihanyi, Miller and Connelly (2006) mentioned that there are more than twenty indexes of internationalization used by scholars. By using different measurements, it might cause inconsistencies between empirical results and internationalization. Hence, before discussing the relation of internationalization and a company's performance, understanding the differences of the indexes is important. We split them into two parts to make further discussion:

\subsubsection{Single Index}

Early studies concentrated on the a number indexes to measure the degree of internationalization, including the following: The ratio of foreign sales to total sales (FSTS), foreign assets to total assets (FATA), or foreign employees to total employees (FETE) (Capar \& Kotabe, 2003; Kwok \& Reeb, 2000).

\subsubsection{Composite Index}

Sullivan (1994), states that the degree of internationalization can be expressed as the sum of FSTS, FPTP, RDI, AI, ESTS, FATA, OSTS, TIME and PDIO. Sullivan tried to measure the internationalization of an enterprise by the above nine indexes, and separated it into three dimensions: performance attributes (what goes on overseas), structural attributes (what resources are overseas), and attitudinal attributes (what is top management's international orientation). Integrative works emphasize that DOI is not an absolute state but a continuous choice that managers make relative to domestic circumstances; therefore, all measures of the degree of internationalization are ratios. As stated by Sullivan, there is no shortage of potential measures. However, our rule of only using archival data restricted including and, if need be, designing measures that we could estimate objectively. Sullivan (1994) noted the following nine measures to operationalize the performance, structural and attitudinal attributes of internationalization.

\section{Performance Attributes}

(i) FSTS, foreign sales as a percentage of total sales.

(ii) FPTP, foreign profits percentage of total profit.

(iii) RDI, research and development intensity, which could be described as the principal means of gaining market share in global competition.

(iv) AI, advertising intensity represents an international firm's marketing function, and could help explain a 
firm's international involvement.

(v) ESTS, export sales as a percentage of total sales.

\section{Structural Attributes}

(i) FATA, foreign assets as a percentage of total assets to estimate the material international character of a firm.

(ii) OSTS, overseas subsidiaries as a percentage of total subsidiaries, corresponding to the number of foreign subsidiaries relative to the company's total number of distinct operating units

\section{Attitudinal Attributes}

(i) TMIE, top managers' international experience, measured by the cumulative duration of top managers' international assignments

(ii) PDIO, psychic dispersion of international operation, measured by estimating the geographical dispersion of the overseas subsidiaries of a firm.

However, Sullivan (1994) asserts that single measures could be biased, as single items do not permit one to take measurement error into account in analyses. The impossibility of determining the reliability of a single measure could thus increase the probability mismeasurement. Sullivan then applies factor analysis by using principal component measurement to obtain the optimum factor loading in order to eliminate the ambiguity through weighted average. As noted "item-total analysis for constructing homogenous measures" is used to obtain the common component which can indicate a consistent measurement method to estimate the internal consistency of a combination of single measures of DOI.

\subsection{Literature Review}

In this section we mainly depict the relevant literature reviews regarding internationalization. There are extensive literatures regarding internationalization as it has become an indispensable topic in the past decades and as globalization has exponentially increased and more cross-national activities are taking place, the study of internationalization across countries has not diminished but rather has become more and more vital. For the purposes of this study, only literatures that are more relevant to the present research are taken into account.

Johanson and Vahlne (1977) indicated that internationalization of firms is a process in which the firms progressively increase their international involvement. They argued that a firm may prefer to choose a closer proximity target market for internationalization and further examined the steps that are taken to constitute the internationalization process of a firm. Their research results indicated that, first are the process-decisions that start the initial export to a country, then it is to establish export channels, in order to start sales branches and subsidiaries, and finally to achieve overseas direct investments as the final step in the process of firm internationalization.

Since past literatures argued that a firm may prefer to choose a closer proximity target market for internationalization and further examined the steps that are taken to constitute the internationalization process of a firm. Dunning (1980) looked at the construction of the eclectic theory of international production, examining the determinants affecting the international production of firms. Their results compare the following features surrounding U.S. manufacturing industries: ownership advantages, location advantages, and lastly, internalization advantages. Sullivan (1994) proceeded to examine combined indexes as a method that could be applied in order to measure the degree of internationalization (DOI) of firms. He proposed that the degree of internationalization is not an absolute state but a continuous choice that managers make relative to domestic circumstances; therefore, all measures of the degree of internationalization could be established as ratios. His results indicated that the integration of several component variables is shown to perform better than the single-item measures. Ramaswamy, Kroeck, and Renforth (1996) further supported and confirmed Sullivan's (1994) research that single variable indexes could be intrinsically unreliable and has, at best, only speculative validity. As such, the construction of a multi-item aggreate index to measure the degree of internationalization is indeed noteworthy and of great utility to understand the nature of the degree of internationalization of firms.

Looking into the determinants of internationalization of firms, Thirkell and Dau (1998) examined the determinants for New Zealand firm's export performance. They noted that foreign language skills are often intertwined with an appreciation of the associated culture, suggesting that higher levels of language and cultural skill may translate into a more effective communications programme. Their final results indicate that firm size, degree of market competition, and R\&D expenditure were found to significantly and positively correlate with marketing orientation. Majocchi and Zucchella (2003) examined the internationalization and performance of a 
set of Italian SMEs. They proposed that target markets with higher affinity or closeness are easier to understand and serve, because they are similar or represent a common market segment. Thus, they are both coherent with an organization that aims to reduce the complexities of foreign market commitment. In other words, they could be more compatible with the typical financial and organizational constraints of the firm. Hsu and Boggs (2003) mainly looked at the relationship of MNEs' performance to the degree of internationalization (linear or curvilinear). Their results shows that there is no immediate evidence of a curvilinear relationship between the degree of internationalization (measured as FSTS) and performance (ROA) and confirms that there is a curvilinear relationship between country scope and performance.

Cunha and Boehe (2008) studied the internationalization of Brazilian retail banks, drawing on strategic management approaches and case research to develop an argument explaining the internationalization of South American retail banks. Their findings claim that Brazilian retail banks may internationalize in order to differentiate themselves vis-à-vis their home country competitors, offering their clients, in a proactive manner, a portfolio of products and services which would not have been available otherwise. Considering the process of internationalisation in retail banking, Spanish Banco Santander developed a competitive advantage by introducing new strategies and systems, acting as a firstmover focused on its core business. Parada, Alemany and Planellas (2009) then futher examined the internationalisation behaviour of Banco Santander towards globalisation, expanding towards the Euro-zone and Latin America. They identified Banco Santander's internationalization process based on three steps. The first step is to develop necessary capabilities in the home market. The second step is to create options for leveraging capabilities in new international markets. The third step consists of acquiring a leading local competitor and a quick international roll-out followed by an implementation of integrated capabilities. Their analysis showed that overall market selection is mostly based on cultural and/or economic proximity, geographic focus and deregulation or increased competition.

Futher looking at more recent internationalization of firms, Banalieva and Sarathy (2011) looked at the contingency theory of internationalization performance (IP) for emerging market multinational enterprises (EM MNEs). They looked at the factors concerning foreign sales, firm age, firm size, market inflation, market growth and market GDP potential together with International performance. Their final results suggests that the IP link is inverted-U shaped for electronics EM MNEs and linear for non-electronics EM MNEs and that these relationships are further enhanced with higher trade liberalization. Polat and Mutlu (2013) examined the degree of internationalization (DOI), market orientation and entrepreneurship orientation within Turkish logistics sector. Their empirical results further showed that there was no relationship between entrepreneurial orientation and the degree of internationalization, and that sector experience, firm age, market orientation and firm size have a significant effect on the degree of internationalization regarding firms within the Turkish logistics sector. Gaur, Kumar, and Singh (2014) investigated emerging economy (EE) firms expanding into international markets according to institutions, resources, and internationalization. They integrated resource- and institution-based views to look at firm $R \& D$ expense, marketing expense, import intensity, export intensity and foreign affliliation, suggesting that firms that can use unique institutional advantages are more likely to advance in the international process of a firm. They found that firms that are affiliated with a business group, have more firm- and group-level international experience, have more technological and marketing resources, and that operate in service industries, are more likely to successfully make their international transition. Azar and Drogendijk (2014) suggested that internationalization improves a firm's ability to innovate and draw into the effect of internationalizing into specific target markets or destinations. Their study also examined whether the psychic distance (measured by Hofstede's cultural dimensions) between target market and home market affects firms' propensity to innovate.

Banking institutions often demonstrate the phenomena of "customer following" and "market seeking", indicating that financial service companies often have a close relationship with other firms that have already invested overseas, De Bonis, Ferri and Rotondi (2015) investigated wheter firm-bank relationships affect firms' internationalization. They found that in fact many manufacturing firms seeking to expand abroad often have a close relationship with financial institutions, where, in some cases, banking firms also follow their customers in cross-border businesses. Their finding indicate that international firms could benefit from a strong relationship with their main bank and vice versa. Bronzini and D'Ignazio (2016) looked at the relationship between bank internationalization and firm exports. Their findings further confirms that there is a positive effect for firm-bank relationships, and that there might be a stronger effect for closer firm-bank relationships more so when banks have established their branches abroad over a certain period of time. Looking at recent global financial crisis and also important factors affecting firm internationalization, Saona (2016) determined that the success of Latin American financial institutions is not just determined by the factors of asset diversification, revenue 
diversification, market concentration and legal/regulatory systems, but al so and substantially by the state of the different regions and markets (such as financial crisis). These might lead to market instability, higher operating costs and higher loan risks in those region's banking systems.

\section{Methodology-Approach of Principal Component Analysis}

The Principal Component Analysis (PCA) procedure, as it name states, finds the principal components of the data. Often, in order to analyze the combination effect of data from different sources, it is necessary to concoct a combined variable. As such, the PCA procedure can find the factor loading of each of the different variables and then we can apply the weights together in order to produce a new combined variable. Principal component analysis was first introduced by Pearson (1901) and then further improved by Hotelling (1933).

Suppose that we have k explanatory variables $x_{i}$. Then we can consider linear functions of these variables:

$$
\begin{gathered}
z_{1}=a_{1} x_{1}+a_{2} x_{2}+\cdots+a_{k} x_{k} \\
z_{2}=b_{1} x_{1}+b_{2} x_{2}+\cdots+b_{k} x_{k} \\
z_{3}=c_{1} x_{1}+c_{2} x_{2}+\cdots+c_{k} x_{k} .
\end{gathered}
$$

And so on...

Suppose we choose the a's so that the variance of $z_{1}$ is maximized subject to the condition that

$$
a_{1}^{2}+a_{1}^{2}+\cdots+a_{k}^{2}=1
$$

This is called the normalization condition. (It is required or else the variance of $z_{1}$ can be increased indefinitely.) $z_{1}$ is then said to be the first principal component. It represents the linear function of the $x$ 's that has the highest variance (subject to the normalization rule). The obtained $z$ 's are the principal components given any set of variables $x_{1}, x_{2} \ldots x_{k}$.

The process of maximizing the variance of the linear function $\mathrm{z}$ subject to the condition that the sum of squares of the coefficients of the $x$ 's is equal to 1 , produces $k$ solutions. Corresponding to these we construct $\mathrm{k}$ linear functions $z_{1}, z_{2} \ldots z_{k}$. These are called the principal components of the $x$ 's. They can be ordered so that

$$
\operatorname{var}\left(z_{1}\right)>\operatorname{var}\left(z_{2}\right)>\cdots>\operatorname{var}\left(z_{k}\right)
$$

$z_{1}$ the one with the highest variance is called the first principal component, $z_{2}$ with the next highest variance is called the second principal component, and so on. These principal components have the following properties:

1. $\operatorname{var}\left(z_{1}\right)+\operatorname{var}\left(z_{2}\right)+\cdots+\operatorname{var}\left(z_{k}\right)=\operatorname{var}\left(x_{1}\right)+\operatorname{var}\left(x_{2}\right)+\cdots+\operatorname{var}\left(x_{k}\right)$, for each components

2. Under the above situation $1, \operatorname{var}\left(x_{i}\right)=\lambda_{i}$, as such $\lambda_{i}$ is the characteristic value for the variance-covariance matrix of the $x_{i}$ and we obtain the principal loading $C_{i}$ for each $x_{i}$ and principal component loading can be obtained by the following equation $C_{i}=\sqrt{\lambda_{i}} * a_{i}$

3. For first component $z_{1}, \sum_{i=1}^{n} a_{1 i}^{2}=1$ and $\sum_{i=1}^{n} a_{1 i}^{2}=\lambda_{i}$ is satisfied, then $C_{1 i}$,

$C_{11}, C_{12}, C_{13} \ldots C_{1 k}$ are the principal components loading of each $z_{1}$

Based on the obtained first components loadings $\left(C_{1 i}\right)$ of each $z_{1}$, we can then multiply them to each corresponding $x_{i}$ and obtained a new combined variable whilst taking the different weights from the different set of variables x's into consideration, i.e., The new obtained value can be estimated as follows:

$$
X=C_{11} * x_{1}+C_{12} * x_{2}+C_{13} * x_{3} \ldots+C_{1 k} * x_{k}
$$

Considering Equation 4, we can construct our degree of internationalization DOI variable for each bank (ie., $\mathrm{X}$ is principal weighted score value of DOI). 
In order to show the values in a more intuitive way, it is possible to perform a Box-cox transformation, where it is possible to better observe the relevance of the size of the variables. Before we do the transformation for $\mathrm{X}$ (principal component score value), we need to normalize the $\mathrm{X}$ variables as such it is divided by the variance of $\mathrm{X}(\operatorname{Var} \mathrm{X})$ as follows:

$$
\mathrm{Z}=\frac{X-E(X)}{\sqrt{\operatorname{Var}(X)}}
$$

After obtaining the normalized $\mathrm{Z}$ from $\mathrm{X}$, the specific Box-cox conversion formula can be applied to show a new scoring index as percentage level (\%) from 0 to 100 , the transformation process is as follows:

$$
\text { Score }=\frac{100}{1+\frac{1}{\exp (Z)}}
$$

Where, Z: normalized principal component weighted score value.

After the Box-cox transformation by Equation 5, a new scoring index from 0 to 100 is obtained. This conversion facilitates observations to more intuitively interpret and understand the perceptual orientation of the results.

\section{Empirical Results of Principal Component Anal ysis for DOI}

Based on the method of principal component analysis as indicated in Equation 4 presented in Section 4, we can obtain the estimated values to detect the degree of internationalization DOI for each selected bank, by using the integrated index (namely composite index as mentioned in Section 3) during the study period of 2000-2015. In this study we then apply the principal component analysis (PCA) by Equation 7 to obtain our estimated DOI value.

$$
\mathrm{DOI}=C_{11} * \mathrm{FATA}+C_{12} * \mathrm{FETE}+C_{13} * \mathrm{FSTS} \ldots+C_{14} * \mathrm{FBTB}
$$

Where:

FATA: each bank's overseas assets over its own total assets

FETE: each bank's overseas equities over its own total equities

FSTS: each bank's overseas sales over its own total sales

FBTB: each bank's overseas facilities and operating units over its own total operating units

The DOI categories were considered based on internationalization components as indicated in previous literatures (Sullivan, 1994) and also taking into consideration of the real business activity of Taiwanese banks operating overseas. Based on Equation 7, we obtain the estimated values to detect the degree of internationalization DOI for each selected bank during the study period of 2000-2015.

As can be seen from Table 3, based on a cross-sectional analysis in the overall period 2000-2015, the average of DOI for each bank, there is an increasing trend for the degree of internationalization of Taiwanese banks as the years go by. The overall average of DOI for each bank across 2000-2015 is 0.061 . The first three highest average DOI under this period ranks as follows: CTBC (0.253), Mega Bank (0.171) and Bank SinoPac (0.149), with the rest mostly ranging between 0.007 and 0.076 . For the period 2000-2007 the average DOI is 0.058 and the first three highest average DOI under this period ranks as follows: CTBC (0.025), Bank SinoPac (0.202) and Mega Bank (0.173), with the rest mostly ranging between 0.002 and 0.093. Within the years 2008-2015 the average DOI is 0.064 and the first three highest average DOI under this period ranks as follows: CTBC (0.256), Mega Bank (0.169) and Cathay United Bank (0.162), with the rest mostly ranging between 0.011 and 0.096 . Based on the time-series analysis, during our study period, the overall highest average DOI belong to the years 2000 (0.065), 2014 (0.073) and 2015 (0.095). The average value of the rest of the DOI rages between 0.053 and 0.062 , as can be seen, the overall values are quite even. As shown in Table 3, the average DOI value of the full period (2000-2015) is 5.91, while the average DOI value (0.064) of the second period (2008-2015) is greater than the average DOI value (0.058) of the first period (2000-2007), it seems to indicate that even after the global financial crisis event, the average degree of internationalization of Taiwanese banks still continues to rise.

Furthermore, utilizing Equation 5 and 6, we then perform the Box-cox transformation for the normalized principal component weighted score value, where a new DOI scoring index as percentage level (\%) from 0 to 100 is obtained in order to better observe the relevance of the variables. This conversion facilitates the observation to more intuitively interpret and understand the perceptual orientation scale of the results (Table 4). 
As can be seen from Table 4, after performing a Box-cox transformation of the normalized principal component weighted values, based on a cross-sectional analysis in the overall period 2000-2015. The overall average of DOI for each bank across 2000-2015 is 50.76. The first three highest average DOI under this period ranks as follows: CTBC (53.159), Mega Bank (52.13) and Bank SinoPac (51.86), with the rest mostly ranging between 50.09 and 50.94. For the period 2000-2007 the average DOI is 50.72 and the first three highest average DOI under this period ranks as follows: CTBC (53.123), Bank SinoPac (52.52) and Mega Bank (52.16), with the rest mostly ranging between 50.03 and 51.16. Within the years 2008-2015 the average DOI is 50.80 and the first three highest average DOI under this period ranks as follows: CTBC (53.196), Mega Bank (52.11) and Cathay United Bank (52.02), with the rest mostly ranging between 50.14 and 51.20. Based on the time-series analysis, during our study period, the overall highest average DOI belong to the years 2000 (50.81), 2014 (50.91) and 2015 (51.19). The average value of the rest of the DOI rages between 50.66 and 50.78, as can be seen, the overall values are quite even. As shown from Table 4, the average DOI value of the full period (2000-2015) is 50.76, while the average DOI value (50.80) of the second period (2008-2015) is greater than the average DOI value (50.72) of the first period (2000-2007), it seems to indicate that even after the global financial crisis event, the average degree of internationalization of Taiwanese banks still continues to rise. Generally speaking, based on the observed score, the DOI of Taiwanese banks are all above the $50 \%$.

\section{Concluding Remarks}

This study mainly focuses on measuring the degree of internationalization (DOI) within the Tai wanese banking industry by principal component analysis (PCA), where the phenomenon can be most clearly identified. Our empirical results reinforce the fact that by using only a single index measurement it may lead to undervaluation of the DOI. Each measurement from the different single

Table 3. Degree of Internationalization of Taiwanese Banks During the Period 2000-2015

\begin{tabular}{|c|c|c|c|c|c|c|c|c|c|c|c|c|c|c|c|c|c|c|c|}
\hline DOI & $\begin{array}{l}\text { Mega } \\
\text { Bank }\end{array}$ & $\begin{array}{l}\text { Bank of } \\
\text { Taiwan }\end{array}$ & $\begin{array}{l}\text { CTBC } \\
\text { Bank }\end{array}$ & $\begin{array}{l}\text { First } \\
\text { Bank }\end{array}$ & $\begin{array}{l}\text { TCB } \\
\text { Bank }\end{array}$ & $\begin{array}{c}\text { TaipeiFubon } \\
\text { Bank }\end{array}$ & $\begin{array}{c}\text { Hua } \\
\text { Nan } \\
\text { CB }\end{array}$ & $\begin{array}{l}\text { Cathay } \\
\text { United } \\
\text { Bank }\end{array}$ & $\begin{array}{l}\text { Chang } \\
\text { Hwa } \\
\text { Bank }\end{array}$ & $\begin{array}{l}\text { Land } \\
\text { Bank }\end{array}$ & $\begin{array}{l}\text { ESun } \\
\text { Bank }\end{array}$ & $\begin{array}{c}\text { Shanghai } \\
\text { CSB }\end{array}$ & $\begin{array}{c}\text { Bank } \\
\text { SinoPac }\end{array}$ & $\begin{array}{c}\text { Taishin } \\
\text { Int } B\end{array}$ & $\begin{array}{c}\text { Taiwan } \\
\text { Business } \\
\text { Bank }\end{array}$ & $\begin{array}{c}\text { Shin } \\
\text { Kong } \\
\text { Bank }\end{array}$ & $\begin{array}{c}\text { Far } \\
\text { Eastem } \\
\text { Bank }\end{array}$ & $\begin{array}{c}\mathrm{Ta} \\
\text { Chong } \\
\text { bank }\end{array}$ & $\begin{array}{c}\text { Average } \\
\text { For Each } \\
\text { Year }\end{array}$ \\
\hline 2000 & 0.217 & 0.053 & 0.240 & 0.085 & 0.015 & 0.045 & 0.039 & 0.068 & 0.04 & 0.013 & 0.051 & 1E:04 & 0.237 & 0.017 & 0.023 & 1E-05 & 0.0240 & $2 \mathrm{E}-04$ & 0.065 \\
\hline 2001 & 0.180 & 0.046 & 0.119 & 0.068 & 0.014 & 0.035 & 0.034 & 0.243 & 0.029 & 0.012 & 0.042 & $1 \mathrm{E}-04$ & 0.221 & 0.015 & 0.017 & $\mathbb{E}-05$ & 0.020 & $1 \mathrm{E}-04$ & 0.061 \\
\hline 2002 & 0.178 & 0.046 & 0.346 & 0.063 & 0.016 & 0.034 & 0.026 & 0.065 & 0.033 & 0.018 & 0.028 & IE-04 & 0.222 & 0.008 & 0.017 & $4 \mathrm{E}-06$ & 0.020 & $9 \mathrm{E}-05$ & 0.062 \\
\hline 2003 & 0.162 & 0.037 & 0.264 & 0.068 & 0.016 & 0.034 & 0.023 & 0.050 & 0.033 & 0.021 & 0.027 & IE:04 & 0.215 & 0.016 & 0.017 & 1E-04 & 0.020 & $9 \mathrm{E}-05$ & 0.056 \\
\hline 2004 & 0.167 & 0.032 & 0.249 & 0.068 & 0.016 & 0.034 & 0.027 & 0.050 & 0.032 & 0.021 & 0.016 & IE-04 & 0.244 & 0.014 & 0.017 & $4 \mathrm{E}-05$ & 0.020 & $3 \mathrm{E}-04$ & 0.056 \\
\hline 2005 & 0.178 & 0.032 & 0.261 & 0.071 & 0.016 & 0.023 & 0.027 & 0.066 & 0.028 & 0.025 & 0.015 & $2 \mathbb{E}-04$ & 0.237 & 0.021 & 0.017 & $-9 \mathrm{E}-06$ & 0.020 & $1 \mathrm{E}-04$ & 0.058 \\
\hline 2006 & 0.150 & 0.032 & 0.277 & 0.069 & 0.014 & 0.017 & 0.030 & 0.107 & 0.028 & 0.026 & 0.014 & 0.013 & 0.116 & 0.021 & 0.017 & 0.007 & 0.020 & 0.014 & 0.054 \\
\hline 2007 & 0.151 & 0.034 & 0.247 & 0.075 & 0.014 & 0.017 & 0.030 & 0.092 & 0.028 & 0.025 & 0.019 & 0.013 & 0.120 & 0.021 & 0.017 & 0.013 & 0.020 & 0.013 & 0.053 \\
\hline 2008 & 0.154 & 0.033 & 0.265 & 0.074 & 0.014 & 0.022 & 0.030 & 0.099 & 0.027 & 0.024 & 0.018 & 0.024 & 0.116 & 0.021 & 0.016 & 0.013 & 0.020 & 0.014 & 0.055 \\
\hline 2009 & 0.157 & 0.030 & 0.257 & 0.080 & 0.014 & 0.022 & 0.030 & 0.121 & 0.027 & 0.023 & 0.017 & 0.023 & 0.096 & 0.015 & 0.017 & 0.013 & 0.020 & 0.012 & 0.054 \\
\hline 2010 & 0.160 & 0.034 & 0.241 & 0.080 & 0.016 & 0.033 & 0.026 & 0.155 & 0.027 & 0.023 & 0.023 & 0.023 & 0.092 & 0.015 & 0.022 & 0.013 & 0.014 & 0.011 & 0.056 \\
\hline 2011 & 0.168 & 0.033 & 0.231 & 0.080 & 0.019 & 0.033 & 0.030 & 0.158 & 0.027 & 0.028 & 0.022 & 0.033 & 0.096 & 0.015 & 0.022 & 0.020 & 0.013 & 0.011 & 0.058 \\
\hline 2012 & 0.172 & 0.033 & 0.226 & 0.078 & 0.019 & 0.033 & 0.037 & 0.160 & 0.026 & 0.028 & 0.031 & 0.041 & 0.092 & 0.015 & 0.022 & 0.014 & 0.013 & 0.011 & 0.058 \\
\hline 2013 & 0.172 & 0.033 & 0.226 & 0.081 & 0.024 & 0.033 & 0.040 & 0.191 & 0.03 & 0.023 & 0.054 & 0.049 & 0.092 & 0.015 & 0.022 & 0.014 & 0.013 & 0.011 & 0.062 \\
\hline 2014 & 0.179 & 0.037 & 0.298 & 0.083 & 0.027 & 0.093 & 0.040 & 0.202 & 0.033 & 0.027 & 0.067 & 0.049 & 0.092 & 0.022 & 0.028 & 0.013 & 0.013 & 0.011 & 0.073 \\
\hline 2015 & 0.19 & 0.049 & 0.305 & 0.089 & 0.038 & 0.112 & 0.047 & 0.206 & 0.037 & 0.032 & 0.088 & 0.321 & 0.092 & 0.021 & 0.038 & 0.020 & 0.013 & 0.011 & 0.095 \\
\hline $2000-2007$ & 0.173 & 0.039 & 0.250 & 0.071 & 0.015 & 0.03 & 0.029 & 0.093 & 0.031 & 0.02 & 0.026 & 0.003 & 0.202 & 0.016 & 0.018 & 0.002 & 0.02 & 0.003 & 0.058 \\
\hline $2008-2015$ & 0.169 & 0.035 & 0.256 & 0.081 & 0.021 & 0.048 & 0.035 & 0.162 & 0.029 & 0.026 & 0.04 & 0.07 & 0.096 & 0.017 & 0.024 & 0.015 & 0.015 & 0.011 & 0.064 \\
\hline $2000-2015$ & 0.171 & 0.037 & 0.253 & 0.076 & 0.018 & 0.039 & 0.032 & 0.127 & 0.03 & 0.023 & 0.033 & 0.037 & 0.149 & 0.017 & 0.021 & 0.009 & 0.018 & 0.007 & 0.061 \\
\hline
\end{tabular}

Source: This Study 
Table 4. DOI of Taiwanese Banks After Box-cox Transformation for the Period 2000-2015

\begin{tabular}{|c|c|c|c|c|c|c|c|c|c|c|c|c|c|c|c|c|c|c|c|}
\hline DOI & $\begin{array}{l}\text { Mega } \\
\text { Bank }\end{array}$ & $\begin{array}{l}\text { Bank } \\
\text { of } \\
\text { Taivan }\end{array}$ & $\begin{array}{l}\text { CTBC } \\
\text { Bank }\end{array}$ & $\begin{array}{l}\text { First } \\
\text { Bank }\end{array}$ & $\begin{array}{l}\text { TCB } \\
\text { Bank }\end{array}$ & $\begin{array}{c}\text { Tapeifubon } \\
\text { Bank }\end{array}$ & $\begin{array}{l}\text { Hua } \\
\text { Nan } \\
\text { CB }\end{array}$ & $\begin{array}{l}\text { Cathay } \\
\text { United } \\
\text { Bank }\end{array}$ & $\begin{array}{l}\text { Chang } \\
\text { Hwa } \\
\text { Bank }\end{array}$ & $\begin{array}{l}\text { Land } \\
\text { Bank }\end{array}$ & $\begin{array}{l}\text { ESun } \\
\text { Bank }\end{array}$ & $\begin{array}{l}\text { Shanghai } \\
\text { CSB }\end{array}$ & $\begin{array}{c}\text { Bank } \\
\text { SmoPac }\end{array}$ & $\begin{array}{l}\text { Taishin } \\
\text { Int B }\end{array}$ & $\begin{array}{c}\text { Tairun } \\
\text { Busisess } \\
\text { Bankl }\end{array}$ & $\begin{array}{l}\text { Shin } \\
\text { Kong } \\
\text { Bank }\end{array}$ & $\begin{array}{c}\text { Far } \\
\text { Easteml } \\
\text { Bank }\end{array}$ & $\begin{array}{c}\text { Ta } \\
\text { Chong } \\
\text { bank }\end{array}$ & $\begin{array}{c}\text { Average } \\
\text { For } \\
\text { Each } \\
\text { Year }\end{array}$ \\
\hline 2000 & 52.71 & 50.67 & 53.00 & 51.06 & 50. & & 50.48 & 508 & 50.50 & 50.16 & ov & J & & 50.21 & & & & 500 & 50.81 \\
\hline 2001 & 52.25 & & 51.48 & . & 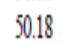 & & & & & 5015 & & & & & & & & & 50.76 \\
\hline 200 & 52 & & 5431 & 50.79 & 50.2 & & & & & & & & & & & & & & 50.78 \\
\hline 2003 & 52 & & $\because \cdots$ & 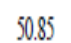 & 50.2 & & & & & & & & & & & & & & CM \\
\hline 2004 & 52 & 50 & 53.10 & 50.86 & 50.20 & & & 50. & & 50.26 & 50 & 50.0 & & 50.18 & & & & & 70 \\
\hline 2005 & 52.22 & 504 & 53.25 & 50.89 & 50.20 & & 33 & 50.83 & 35 & 50.32 & 5010 & 50 & in & 5026 & & & & n & 50.72 \\
\hline 2006 & 51 & & 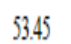 & 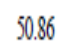 & 50.1 & & & & & 502 & & & & & & & & & 50.67 \\
\hline 200 & 51.89 & 50.4 & 53.08 & 50.94 & 50.18 & & & 51.1. & 50. & 50.31 & $N_{0}$ & & 51. & 50.2 & & & & & 66 \\
\hline 2008 & 51.93 & 50.42 & 5331 & 50.93 & 0. & & & (1) & & 00 & 0 & & & 50.2 & & & & & 69 \\
\hline 2009 & 51.96 & 50.37 & 53.20 & 51.00 & 50.1 & & & 51.5 & $\pi$ & 50.29 & Jo. & & & 50.19 & & & & & 50.68 \\
\hline 2010 & 51.99 & 50.42 & 53.00 & 51.00 & 50.20 & & 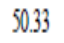 & 51.94 & 50.33 & 50.29 & 50.29 & 50.3 & 51.15 & 50.18 & & 17 & 17 & 50.14 & 50.70 \\
\hline 2011 & 52.10 & & 5289 & 51.00 & 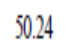 & & & & & 50.35 & 5077 & & & & & & & & 5072 \\
\hline 201 & 5 & & 00 & 50 & 50 & & & & & 5025 & 50 & & & & & & & & n. \\
\hline 201. & 52.1 & 50. & 528 & 51.01 & 50. & & & 52. & 50. & 50. & 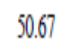 & & 51 & 50. & & & & & 78 \\
\hline 201 & 52 & 50 & 53 & 51. & 20 & & & & & 50 & & & & & & & & & 50.91 \\
\hline 2015 & 52.38 & 50.61 & 53.80 & 51.12 & 50.47 & & & 52.58 & N & 50.40 & 51.10 & 34.00 & 51.15 & 50.27 & +0 & .25 & 50.16 & 50.14 & 51.19 \\
\hline $2000-2007$ & 52.16 & 50.49 & 53.123 & 50.88 & 50.19 & & & 51.16 & 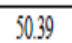 & 50.25 & 50.33 & 50 & 5252 & 50.21 & & 03 & 25 & 50.04 & 50.72 \\
\hline & 52.11 & 50.4 & 53.19 & 51.01 & 50.2 & & & 52 & & 50.33 & 50 & & 51 & & & & & & 50.80 \\
\hline $2000-201$ & 52.13 & 50.47 & 53.159 & 50.94 & 50.23 & N. & J. & 51.54 & 00.38 & 50.29 & 50.42 & 50.4 & 51.86 & 50.21 & 30.24 & 50.11 & 50.22 & 50.09 & 50.76 \\
\hline
\end{tabular}

Source: This Study

Index yield different partial results for the DOI measurement of Taiwanese banks, as such it cannot completely justify the actual DOI for Taiwanese banks. Integrative works emphasize that DOI is not an absolute state but a continuous choice that managers make relative to domestic circumstances; therefore, all measures of the degree of internationalization are ratios. Under the PCA weighted average, the results show an increasing trend for the DOI of Taiwanese banking industry as measured by the combination of FATA (each bank's overseas assets over its own total assets), FETE (each bank's overseas equities over its own total equities), FSTS (each bank's overseas sales over its own total sales) and FBTB (each bank's overseas facilities and operating units over its own total operating units). We can thus conclude that despite recent economic downturns, the degree of internationalization of Tai wanese banks indicate that Tai wanese financial institutions still maintain their global presence, as such, bolstering Taiwanese financial firms and enhancing its internationalization core might be a necessary pathway to strengthen and reinforce the internationalization of other firms across industries. Under the Box-cox transformation, the DOI scoring index as percentage level (\%) from 0 to 100 shows that the relevance of the variables are mostly above 50, again indicating that the DOI of the observed Taiwanese banks are quite strong. These results thus support the existence and importance of the DOI of Tai wanese banks and further point out the necessity to continue perusing and understanding the nature of the relationship. Hopefully, the empirical results of this study may contribute additional facts to support or enhance the relative theories of internationalization of Taiwanese banking firms. In addition, present complimentary and more realistic information regarding the degree of internationalization for Taiwanese financial institutions. At the same time, provide substantial groundwork and adding value to future international management research and investigations. Meanwhile, it could also help to achieve better investment decision-making for business strategies purposes and government policies.

\section{References}

Annavarjula, M., \& Beldona, S. (2000). Multinationality-performance Relationship: A Review and Reconceptualization. International Journal of Organizational Analysis, 8(1), 48-67. https://doi.org/10.1108/eb028910

Azar, G. S., \& Drogendijk, R. (2014). Psychic Distance, Innovation, and Firm Performance. Management International Review, 54, 581-613. https://doi.org/10.1007/s11575-014-0219-2

Banalieva, E., \& Sarathy, R. (2011). A Contingency Theory of Internationalization Performance for Emerging Market Multinational Enterprises. Management International Review, 593-634. https://doi.org/10.1007/s11575-011-0093-0 
Bronzini, R., \& D’Ignazio, A. (2016). Bank Internationalization and Firm Exports: Evidence from Matched Firm-Bank Data. Bank of Italy, 16, 1055. https://doi.org/10.2139/ssrn.2777973

Brouwer, A. E., Mariotti, I., \& Van Ommeren, J. N. (2004). The Firm Relocation Decision: An Empirical Investigation. The Annals of Regional Science, 38, 335-347. https://doi.org/10.1007/s00168-004-0198-5

Capar, N., \& Kotabe, M. (2003). The Relationship Between International Diversification and Performance in Service Firms. Journal of International Business Studies, 34(4), 345. https://doi.org/10.1057/palgrave.jibs.8400036

Chen, Y. C. (2012). Taiwan Industry Reports: 2013 Banking Industry. Taiwan Institute of Economic Research, $1-5$.

Cunha, S., \& Boehe, D. M. (2008). Why do Banks Internationalize? The Distinctive Strategy of a Brazilian Retail Bank. Encontro da Anpad, 1-16.

De Bonis, R., Ferri, G., \& Rotondi, Z. (2015). Do Firm-bank Relationships Affect Firms' Internationalization? International Economics, 60-80.

Dunning, J. (1980). Toward an Eclectic Theory of International Production: Some Empirical Tests. Journal of International Business Studies, 11(1), 9-31. https://doi.org/10.1057/palgrave.jibs.8490593

Gaur, A. S., Kumar, V., \& Singh, D. (2014). Institutions, Resources, and Internationalization of Emerging Economy Firms. Journal of World Business, 49, 1-20. https://doi.org/10.1016/j.jwb.2013.04.002

Hitt, M., Tihanyi, L., Miller, T., \& Connelly, B. (2006). International Diversification: Antecedents, Outcomes, and Moderators. Journal Of Management, 32(6), 831-867. https://doi.org/10.1177/0149206306293575

Hotelling, H. (1933). Analysis of a Complex of Statistical Variables into Principal Components. Journal of Educational Psychology, 24, 417-441. https://doi.org/10.1037/h0071325

Hsu, C. C., \& Boggs, D. J. (2003). Internationalization and Performance: Traditional Measures and Their Decomposition. Multinational Business Review, 11(3), 23. https://doi.org/10.1108/1525383X200300015

Johanson, J., \& Vahlne, J. (1977). The Internationalization Process of the Firm-A Model of Knowledge Development and Increasing Foreign Market Commitments. Journal Of International Business Studies, 8(1), 23. https://doi.org/10.1057/palgrave.jibs.8490676

Kwok, C., \& Reeb, D. (2000). Internationalization and Firm Risk: An Upstream-Downstream Hypothesis. Journal of International Business Studies, 31(4),611. https://doi.org/10.1057/palgrave.jibs.8490925

Lin, T., \& Huang, W. (2013). The Relationship Between the Managerial Philosophy of Peace Culture and Corporate Financial Performance: Mediating Effect of the Differential Cross-Cultural Management. Taiwan Journal of International Business Studies, 7(1), 45-69.

Majocchi, A., \& Zucchella, A. (2003). Internationalization and Performance Findings from a Set of Italian SMEs. International Small Business Journal, 21(3), 249-268. https://doi.org/10.1177/02662426030213001

Manjón-Antolín, M. C., \& Arauzo-Carod, J. M. (2011). Locations and Relocations: Determinants, Modelling and Interrelations. Annual regional science, 47, 131-146. https://doi.org/10.1007/s00168-009-0360-1

Nilsson, K., Olofsson, E., \& Sennevik, M. (2005). Get Taiwanized! Swedish Firms' Change of Entry Mode. Internationella Handelshogskolan, 1-40.

Parada, P., Alemany, L., \& Planellas, M. (2009). The Internationalisation of Retail Banking: Banco Santander's Journey towards Globalisation. Long Range Planning, 42, 654-677. https://doi.org/10.1016/j.lrp.2009.09.006

Pearson, K. (1901). On lines and planes of closest fit to systems of points in space. Philosophical Magazine, 2, 559-572. https://doi.org/10.1080/14786440109462720

Perlmutter, A. (1969). Military and Politics in Israel: Nation-building and Role Expansion. London: London Cass.

Polat, İ., \& Mutlu, H. (2013). Degree of Internationalization in Logistics Sector and Strategic Orientations. Scientific Journal of Logistics, 9(2), 91-102.

Porter, M. E. (1990). The Competitive Advantage of Nations. Harvard Business Review, 74-91. https://doi.org/10.1007/978-1-349-11336-1

Ramaswamy, K., Kroeck, K., \& Renforth, W. (1996). Measuring the Degree of Internationalization of a Firm: A 
Comment. Journal of International Business Studies, 27(1), 167-177. https://doi.org/10.1057/palgrave.jibs.8490131

Sanna-Randaccio, F. (1996). New Protectionism and Multinational Companies. Journal of International Economics, 41(1), 29-51. https://doi.org/10.1016/S0022-1996(96)01430-4

Saona, P. (2016). Intra- and Extra-bank Determinants of Latin American Banks' Profitability. International Review of Economics and Finance, 45, 197-214. https://doi.org/10.1016/j.iref.2016.06.004

Seth, R., Nolle, D. E., \& Mohanty, S. K. (1998). Do Banks Follow Their Customers Abroad? Financial Markets, Institutions and Instruments, 7(4), 1-25. https://doi.org/10.1111/1468-0416.00021

Sullivan, D. (1994). Measuring the Degree of Internationalization of a Firm. Journal of International Business Studies, 25(2), 325-342. https://doi.org/10.1057/palgrave.jibs.8490203

Thirkell, P. C., \& Dau, R. (1998). Export Performance: Success Determinants for New Zealand Manufacturing Exporters. European Journal of Marketing, 32, 813-829. https://doi.org/10.1108/03090569810232273

Tomlin, K. M. (2008). Japanese FDI into U.S. Service Industries: Exchange Rate Changes and Services Tradability. Japan and the World Economy, 20, 521-541. https://doi.org/10.1016/j.japwor.2007.04.002

Wright, A. (2002). The Impact of Competition on the Operations of Foreign Banks in Australia in the Post-deregulation Period. Journal of International Financial Markets, Institutions and Money, 359-375. https://doi.org/10.1016/S1042-4431(02)00019-7

\section{Copyrights}

Copyright for this article is retained by the author(s), with first publication rights granted to the journal.

This is an open-access article distributed under the terms and conditions of the Creative Commons Attribution license (http://creativecommons.org/licenses/by/4.0/). 